\title{
Condition and Development Characteristics of The Russian Market of Information Technilogies
}

\author{
Bagautdinova N.G.a \\ Khadiullina G.N. ${ }^{b}$ \\ Shevko N.R.c1 \\ Pratchenko O.V.d \\ a bcd Kazan Federal University, Kazan, 420008, Russia \\ ${ }^{1}$ Email address: verkbund@gmail.com
}

Doi:10.5901/mjss.2014.v5n12p21

\begin{abstract}
Introduction of modern information technologies into all spheres of life brought to formation of the new market segment market of information technologies. The article considers the role of market of information technologies in development of world economy, analyses the main tendencies of development of market of information technologies and presents conservative, innovative forecasts and target prediction of development of this market segment in the Russian economy, considers necessity of state control of market of information technologies using methods of budget-financial, money-and-credit and administrativelegal instruments.
\end{abstract}

Keywords: information services, information product, information resources, modern information technologies, information society, convergence, globalization, market of information technologies (IT).

\section{Introduction}

Rapid development of information technologies and increase of their influence on social-economic development of the society are the integral part of development of information society, transition to network economics. Nowadays stable economic growth is one of the main priority tasks in Russia. Economic growth can be stimulated in two ways: first, appropriate macroeconomic policy making aimed at general financial-economic stabilization, formation of favorable macroeconomic and investment climate, reform of national and administration management, improvement of manufacturing and social infrastructure; second, on the basis of implementation of economic policy on the level of individual industries aimed at solving of target problems of reforming and development of certain types of economic activity. In this case implementation of industry policy can be the next stage of reforms and development of country economy after general economic problem solving, and it can be implemented at the same time with them as well. Industrial economy is the part of industrial national policy, as well as the result of consolidated efforts of business and state.

This article is devoted to the problems of development of one of the key - from the point of view of long-term economic growth - industries, that is to the sector of information technologies and to the measures of public regulation aimed at development of this industry and support in choice of innovatively oriented strategy on the part of business community.

\section{Methodology}

Economic development is closely connected with development of science and technology. Long process of accumulation of scientific knowledge with definite time range - in the form of scientific discoveries - is implemented in technical and technological innovations, which, in its turn, leads to changes in methods of business activities management on enterprises and in macroeconomic mechanisms of regulation used by the state [2, 4]. Contemporary society is impossible without information support of all spheres of its activities. Information society is characterized by high level of development of information and telecommunications technologies and their intensive used by people, business and 
national authorities $[3,6]$.

In contemporary conditions of dynamic development of the society and complication of technical and social infrastructure information becomes the same important strategic resource as the traditional material and energetic resources. Modern information technologies which allow to create, keep, process and provide effective ways of providing of information resources to the customer, became an important factor of public life and means of means of effectiveness increase of management (management multiplier) of all spheres of public activity. Level of use of information becomes one of the important factors of successful economic development and competitiveness on the domestic, as well on the foreign markets.

Sector of information and communication technologies (ICT) is the most dynamically developing sector of modern world economy. If the sector of communications - one of the important parts of this sphere - has been already developing for 100 years (in the world, as well as in Russia), the history of the sector of information technologies which plays the role of the locomotive of modern economic growth of many developed countries is not longer than the quarter of a century. At that nowadays its important is so great that it became the basis of formation of information or "new economy". Information economy is not the only - and at the same time one of the most important - factors of future economic growth of the country.

It's necessary to provide favorable conditions for the development of IT-sector for development of economics of the Russian Federation. It can be reached with the help of support of the sector from the side of the state, as well as by attracting great investment from different sources into the sector. Now in Russia the sector of information technologies is rather less developed than in many developed countries of the world. It hinders further development of national economy.

Detailed analysis of the history and results of development, further changes and tendencies of long-term growth of the sector of information technologies in Russia and their comparison with world indexes and tendencies allow to find out positive and negative factors of development of the sector in the Russian Federation. Thus, from one side, the level of development of IT-sector in the country is rather low, from the other side, its potential and investment attractiveness are high. Great economic and investment potential of the sector of information technologies in Russia is caused by increasing demands in the use of modern technologies in different economic sectors, great intellectual and human potential, fast economic growth of the country and world tendencies of economic development, according to which information sector plays ever-increasing role.

\section{Results}

Support of development of information economic sector cannot be restricted by general questions. Only understanding of deep basis and tendencies of the sector development will help the state to establish effective long-run policy and to make the right choice in priorities of long-term development. Only common effort of the state and private business can change situation in the sector for better and propel to the new qualitative level. In this case private business will be the main engine of the process, but maximum national support of business development - especially on early stages of its development - is necessary for the sector as well.

Acceleration of the rate of scientific and technical progress in the second half of the XX century greatly accelerated the pace of economic development. Constant acceleration of change of obsolete technological structures on the basis of intensification of introduction of the results of scientific discoveries and inventions into manufacturing leads to cost savings, improvement of the effectiveness and industrial growth, which, in its turn, impacts on economic growth of countries. In economic indicators it's expressed in rise in labor productivity and increase in revenue per capita. Role of science and technics in economic sphere made the science into the most important productive power, on the development of which from 2 to $5 \%$ of GDP of developed countries is spent. Under current conditions the level of costs for Research and Development determines in many ways the level of economical development, although other factors also contribute to this development.

Urgent character of development of information products and services in conditions of modern dynamic development of the society, complication of technical and social infrastructure, when information becomes strategic resource, determine further economic development. Modern information technologies became and important factor and means of improvement of the management effectiveness of all spheres of public activities. Level of information support becomes one of the essential factors of success of the economic development process and competitiveness of entities of macro- and microeconomics on different-scale markets.

Study of the place and the role of IT-technologies in organizational-functional structure of particular enterprise, as well as the whole country, taking into account modern state-of-the-art capabilities, predetermined necessity of separation of concerns and significance. The role of the IT-sector is to maintain sustainable development by providing management 
process efficiency on condition of stimulation of further improvement of its mechanism by providing common information space, unimpeded communications in internal environment and quick efficient feed-back with external environment.

Results of development of national IT-market in 2012 show that - with the slowing down of this sector $(+3,9 \%)-$ they exceed worldwide average figures by half. According to official data, in the segment of expenses for IT-equipment in 2010 the Russian Federation was one of the world's top ten leading countries with the indicator of total costs, exceeding worldwide average value for $12 \%$. Thus, per capita of this indicator Russia was behind the countries of Western Europe and the USA 3-5 times. However, concerning expenses for software Russia takes the $16^{\text {th }}$ place being behind the worldwide average value for 55\%, behind the USA and Western Europe - accordingly in 20 and 10 times. Concerning ITservices the situation is much worse: the $22^{\text {nd }}$ place (lag accordingly for $66 \%$, in 24 and 17 times) $[2,8,11]$.

Research development in the sphere of creating of common management environment and common information space sharing, transportation infrastructure, development of research in the sphere of new principles organization of computing and creation of computing architecture, based on new paradigms, researches in the sphere of computerassisted learning systems based on new methods and algorithms, studies in the sphere of telecommunications infrastructures with terabit speed of information transfer, development of supercomputer calculations thanks to development of new algorithms for solution of application tasks with complicated logic of computation process, etc., are referred to the key scientific-technological trends which form IT-market and power.

According to estimates of International Data Corporation (IDC) - analytical company which specializes in information technologies market research, in the nearest five years the Russian IT-market will grow for only 5-7\% a year. At that the market growth will be determined by investments into "the third IT-platform", i.e. into mobile devices, applications for them, social networks and cloud technologies [13]. According to the information of IDC, today less than $50 \%$ of European companies are ready to work with such part of "the third platform", as Big Data. In this case social networks become more and more popular.

The share of "the third platform" in the structure of the IT-market size will be increasing together with the growth of necessity to use mobile devices. According to IDC, by 2012 smartphones share on the personal devices market has almost been $50 \%$, which was $11,2 \mathrm{mln}$. pieces. Another half of personal devices is personal computers (PC) $(4,3$ mln.pieces), notebooks $(8,4 \mathrm{mln}$.) and tablet PCs $(900 \mathrm{mln}$.). it is expected that by 2015 there will be $17,7 \mathrm{mln}$. smartphones, 3,9 mln. personal computers, $13 \mathrm{mln}$. notebooks and 3,2 mln. tablet PCs on the Russian market [14].

Development of computer technology. communications infrastructure, telecommunications networks and distributed data processing allowed to make revolutionary breakthrough and shape tendencies of further development. ITtechnologies market is one of the types of industrial sector market, it is characterized by principles of its functioning, and at the same time production presented on this market has a set of special features. They are the compatibility and direct interaction. At that globalization process influences the condition of this market. Thus, the information technologies market is transformed towards orientation of exactly services in the sphere of high technologies, in this case considerable part of these services will be given by remote access from developing countries. Unlike industrial sectors where international division of labor has already been formed, geographical distribution of the sector of information technologies has not been finished, and Russia has the chance to increase considerably its share on this market on the global basis.

Introduction of modern information technologies into social sphere, economics, public administration, as well as into different public processes is the most important part of accelerated development of Russia, of structural transformations in economics and corresponding reform of public administration. It is reflected in growing domestic demand for information technologies. However, in spite of impressing growth rates, absolute size of the IT-sector in Russia is still rather small. IT- market is only 1,4\% from GDP of Russia. For comparison, in the USA the size of IT-market exceeds $\$ 500 \mathrm{bln}$., which is more than 5\% of GDP. At that strong heel into the side of imported hardware-engineering support still remains on the Russian market, while the services market of IT (mainly, domestic) is only 30 percent of the total volume, and the software market - 14 percent [7].

In the Russian Federation the state is the active customer of information technologies. As in developed foreign countries, during the last 5 years the demand share of the state in IT sector was about 30 percent being significant stimulus of the sector development. Significant volume of demand falls on several big companies which are under state control. The rest volume of demand mainly falls on enterprises of financial and oil and gas sphere, and - in a less degree - on enterprises of communications and trade. Metallurgy, machine manufacturing, transport and other industrial sectors greatly fall behind in using of IT.

Level of expansion of information technologies among Russian citizens is still far from indicators of developed countries. However, recently there is rapid growth in this connection in Russia. It is caused - as in industrywide - by weak maturity of this economic segment and «started only a few years ago market development with practically zero markers». In connection with rapid development and introduction of modern IT-technologies into all life spheres and increase of 
influence on economic growth, it was necessary to compare levels of their development in different countries of the world, which led to creation of methodology of making of rating of countries on the level of information support.

Level of information support is the most important indicator of competitiveness of countries in modern economics. A lot of authoritative international organizations, such as World Bank, Economic Forum in Davos, United Nations Conference on Trade and Development of United Nations, UNESCO, Paris Institute of administration (INSEAD), International Telecommunication Union (ITU) and others take part in making of rating of readiness of countries for information society (network economics). Building of indexes of participation in network economics is one of the way to compare countries concerning the level of information support. In five most common ratings (DOI - Digital Opportunity Index, NRI - Networked Readiness Index, Information Society Index - ISI, Digital Access Index - DAI, Monitoring Index of Digital Divide) reciprocal rating of countries is approximately the same. Comparative analysis of range of 10 countries in different indexes of readiness for network economics is presented in table 1.

Table 1: Comparative analysis of 10 countries in different indexes of readiness for network economics [3]

\begin{tabular}{|c|c|c|c|c|c|c|}
\hline Country & DOI & NRI & ISI & DAI & DIVIDE & TOTAL \\
\hline India & 10 & 7 & 10 & 10 & 10 & 47 \\
\hline China & 9 & 8 & 9 & 9 & 9 & 44 \\
\hline Russia & 8 & 9 & 8 & 8 & 8 & 41 \\
\hline Poland & 7 & 10 & 7 & 7 & 7 & 38 \\
\hline USA & 6 & 2 & 4 & 6 & 4 & 22 \\
\hline Hong Kong & 2 & 4 & 6 & 5 & 5 & 22 \\
\hline South Korea & 1 & 6 & 5 & 3 & 6 & 21 \\
\hline Netherlands & 5 & 5 & 3 & 4 & 3 & 20 \\
\hline Sweden & 4 & 3 & 1 & 1 & 1 & 10 \\
\hline Denmark & 3 & 1 & 2 & 2 & 2 & 10 \\
\hline
\end{tabular}

Denmark, Sweden, South Korea, Hong Kong, Netherlands, USA are the world leaders of readiness for network economics. Poland, Russia, China, India are the countries overtaking the main group.

It is evident that possibilities of the countries concerning formation of information economics with GDP per capita of more than $\$ 20000$ and less than $\$ 2000$ are incomparable. In this connection for estimate of effort of governments for creation of necessary conditions of transition to information economics it is important to know how much wish and support of the country in preparing for network economics are in advance of its GDP. The results were the following: South Korea, Taiwan, Hong Kong, Singapore, Canada, China, Russia, Poland. Rich countries - the USA, Switzerland, , France, Belgium, Germany, Great Britain, Italy, Austria - as well as some comparatively poor countries - South Africa, Mexico, Venezuela - pay less attention to network economics infrastructure development than GDP allows them.

In the research process the following correspondence of ration of DOI index and GDP per capita is defined [6]:

$\mathrm{DOI}=0,1227 \ln (\mathrm{GDP})-0,6298$, with $\mathrm{R} 2=0,8573$.

Real large-scale informational support of society is necessary so the volume of information will be effectively used for solution of real problems. Its implementation requires special information policy on all levels (national, industrial, regional).

\section{Conclusion}

Information policy is special activities on reaching socially important aims. National policy of formation and development of common information space of Russia and corresponding national information resources should be implemented with account of interests of public federal authorities, public authorities of subjects of Federation, local authorities, entities and persons. It should take into account possibilities of international cooperation in the sphere of information technologies, products and services, real possibilities of home information industry in conditions of market economy.

Creation of information society and entry into international information society is the long-term strategic aim of information policy. Creation of integrated information space as the basis of solution of tasks of all levels - socialeconomic, political, cultural development and national security - is the basis of such transition. 


\section{References}

Official site of International Data Corporation (IDC): http://idcrussia.com/ru/ free access.

Bell D. The Coming of Post-industrial Society. A Venture in Social Forecasting. N.Y., Basic Books, Inc., 1973.

Glebova I.S., Rodnyansky D., Sadyrtdinov R., Khabibrakhmanova R. and Yasnitskaya Y. Evaluation of Corporate Social Responsibility of Russian Companies Based on Nonfinancial Reportingll Middle-East Journal of Scientific Research 13 (Socio-Economic Sciences and Humanities): 143-148, 2013.

Ajupov A.A. The Design and Use of Swap-Contracts in the Financial Markets // World Applied Sciences Journal, 27(13), 2013, pp. 1-4.

Castells M. The Information Age: Economy, Society and Culture. Vol. I. The Rise of the Network Society. Blackwell Publishers. Maiden, Oxford, 1996.

Ismagilova G.N., Safiullin L.N., Bagautdinova N.G. Tourism development in region based on historical heritage. Life Science Journal 2014; 11(6s):363-367.

Masuda Y. The Information Society as Postindustrial Society. Washington: World Future Soc ., 1983.

Gainova R.A., Shaidullin R.N., Safiullin L.N. and Maratkanova E.M. Infrastructural Component in Maintenance of Competitiveness of Region// World Applied Sciences Journal, 27(13), 2013, pp. 97-101.

Safiullin M.R., Samigullin I.G. and Safiullin L.N. Model of Management of Competitiveness of a Machine-building Complex/l World Applied Sciences Journal, 27(13), 2013, pp. 212-216.

Porat M., Rubin M. The Information Society: Development and Measurement. Washington, 1978.

Ulesov D.V., Murtazina G., Safiullin L.N. and Saipullaev U.A. Special Aspects of Development of Business in the Knowledge-Based Economy //World Applied Sciences Journal, 27(13), 2013, pp. 189-192.

Fakhrutdinova, E., Kolesnikova, J., Yurieva, O., Kamasheva, A. The commercialization of intangible assets in the information society/l World Applied Sciences Journal. Volume 27, Issue 13, 2013, Pages 82-86.

Safiullin L.N., Fatkhiev A.M., Safiullina L.M. Projected trends and problems of education. Life Science Journal 2014; 11 (6s): $384-387$

Rheingold H. The Virtual Community: Homesteading on the Electronic Frontier. Reading, MA: AddisonWesley, 1993.

Askhatova L.I., Fatkhiev A.M., Safiullin L.N. and Safiullina A.M. Competitive Strategies Formation in High Technology Enterprise // World Applied Sciences Journal, 27(13), 2013, pp. 20-23.

Roberts L., Merrill T. Toward a Cooperative Network of Time-Shared Computers. Fall AFIPS Conf., Oct. 1996. 
